\title{
PERTUMBUHAN DAN TINGKAT MORBIDITAS PADA BAYI USIA 7-12 BULAN BERDASARKAN STATUS PEMBERIAN ASI DI WILAYAH PUSKESMAS GILINGAN KECAMATAN BANJARSARI SURAKARTA
}

\author{
Indah Nurhayati ${ }^{1}$, Endang Nur Widyaningsih ${ }^{2}$, Agus Subagyo $^{3}$ \\ ${ }^{1}$ Rumah Sakit Umum Bhakti Bunda Jl. Mayjend Panjaitan No. 176, Penanggungan, \\ Malang, Kota Malang, Jawa Timur 65113. Email: ${ }^{1}$ indah.indutnur@gmail.com \\ ${ }^{2}$ Program Studi Ilmu Gizi Fakultas Ilmu Kesehatan Universitas Muhammadiyah \\ Surakarta. Jl. A. Yani, Pabelan, Kartasura, Surakarta. Email: ${ }^{2}$ en239@ums.ac.id \\ ${ }^{3}$ Dinas Kesehatan Kota Surakarta. Komplek Balaikota. J1. Jendral Sudirman No. 2 \\ Surakarta. Email: ${ }^{3}$ agus_sby70@yahoo.com
}

\begin{abstract}
ABSTRAK
ASI selain dapat membantu dalam proses pertumbuhan, juga dapat melindungi bayi dari berbagai penyakit infeksi seperti diare dan ISPA. Tujuan dari penelitian ini adalah untuk mengetahui pengaruh status pemberian ASI terhadap pertumbuhan dan tingkat morbiditas pada bayi usia 7-12 bulan di Wilayah Puskesmas Gilingan. Penelitian ini menggunakan rancangan studi kohort retrospektif, yang dilakukan di posyandu wilayah Puskesmas Gilingan. Total sampel pada penelitian ini sebanyak 58 responden, pengambilan sampel menggunakan Consecutive Sampling. Instrumen penelitian berupa kuesioner ASI eksklusif, tingkat morbiditas dan KMS. Teknik analisis uji adalah $C h i$ Square. Hasil penelitian ini adalah tidak ada pengaruh status pemberian ASI terhadap pertumbuhan bayi usia 7-12 bulan dengan $p$ $=0,378$ nilai $\mathrm{RR} 1,667$ (IK 95\% = 0,697-3,984). Tidak terdapat pengaruh status pemberian ASI terhadap kejadian ISPA pada bayi usia 7-12 bulan dengan $p=0,066$ nilai RR 1,800 (IK 95\% = 1,011-3,204). Tidak ada pengaruh status pemberian ASI terhadap kejadian diare pada bayi usia 7-12 bulan dengan $p=0,564$ nilai RR 1,158 (IK 95\% = $0,829-1,618)$.
\end{abstract}

Kata kunci: ASI ekslusif, diare, ISPA, pertumbuhan bayi

\begin{abstract}
Breast milk not only plays a role in the growth process but also can protect infants from various infectious diseases such as diarrhea and upper respiratory tract infection (URTI). The purpose of the study was to determine the effect of breastfeeding status on the growth and morbidity rate in infants aged 7-12 months in Puskesmas Gilingan. The study used a retrospective cohort study, conducted at posyandu of Gilingan Community Health Center. Total samples in this study were 58 respondents, with Consecutive Sampling. The research instruments were exclusive breastfeeding questionnaire, morbidity level, and KMS. The Chi-square was used in the statistical test. The results indicated that there was no influence of breastfeeding status on infant growth 7-12 months with $\mathrm{p}=0.378$ value $\mathrm{RR} 1.667$ (95\% IK $=0.697$ -
\end{abstract}


3,984). There was no influence of breastfeeding status on URTI in infants aged 7-12 months with $\mathrm{p}=0.066 \mathrm{RR}$ value of $1.800(95 \% \mathrm{IK}$ $=1.011-3.204)$. There was no influence of breastfeeding status on diarrhea occurrence in infants aged 7-12 months with $\mathrm{p}=0.564 \mathrm{RR}$ value of $1.158(95 \% \mathrm{IK}=0.829-1.618)$.

Keywords: Exclusive breastfeeding, diarrhea, URTI, baby growth

\section{PENDAHULUAN}

Masalah gizi dapat terjadi di setiap siklus kehidupan, dimulai sejak dalam masa kandungan (janin), bayi, anak-anak, remaja, dewasa dan usia lanjut. Setiap tahap kehidupan memerlukan zat gizi yang sangat berperan dalam proses pertumbuhan dan perkembangan (Sulistyoningsih, 2010). Pertumbuhan dan perkembangan bayi sangat ditentukan dari zat gizi yang diperoleh yaitu zat gizi yang berasal dari Air Susu Ibu (ASI). ASI tanpa tambahan makanan lain sudah dapat mencukupi kebutuhan zat gizi dalam proses pertumbuhan selama usia enam bulan, karena ASI merupakan larutan kompleks yang mengandung karbohidrat, lemak dan protein yang cukup sebagai sumber energi yang dibutuhkan dalam proses pertumbuhan bayi. Pemberian ASI tanpa tambahan makanan lain selama enam bulan disebut dengan pemberian ASI secara eksklusif (Siregar, 2004).

Kandungan ASI selain dapat membantu dalam proses pertumbuhan, ASI juga dapat melindungi bayi dari berbagai penyakit infeksi (Suraatmaja, 2007). Penelitian Fitriyah dan Sulistyawati (2013), menunjukkan bahwa pemberian ASI eksklusif pada bayi umur 7-12 bulan berhubungan dengan kejadian morbiditas diare dan ISPA (Infeksi Saluran Pernapasan Akut). Hal ini dapat disebabkan karena pada ASI mengandung antibodi seperti Lactobacillus bafidus, laktoferin, lisosim, sIgA, yang dapat membantu bayi membangun sistem kekebalan tubuh terhadap berbagai macam sumber penyakit (Sinaga, 2012).
Berdasarkan Survei Kesehatan Rumah Tangga (SKRT) tahun 2009, penyakit ISPA merupakan salah satu penyakit utama penyebab kematian bayi usia 0-11 bulan dan balita. Penyebab kesakitan dan kematian bayi yang terjadi saat ini tidak hanya disebabkan oleh penyakit ISPA, namun juga disebabkan karena kejadian diare. Fitriyah dan Sulistyawati (2013) menjelaskan, untuk mencegah penyakit dan kematian yang disebabkan oleh penyakit infeksi seperti ISPA dan diare pada bayi, salah satu upayanya yaitu dapat dilakukan dengan pemberian Air Susu Ibu (ASI) secara eksklusif.

Angka kecukupan ASI di Indonesia belum mencapai target. Berdasarkan Rikesdas 2013, persentase pemberian ASI saja dalam 24 jam terakhir semakin menurun seiring meningkatnya umur bayi dengan persentase terendah pada anak umur 6 bulan sebanyak 30,2\%. Berdasarkan data yang diperoleh dari Profil Kesehatan Provinsi Jawa Tengah tahun 2012 menunjukkan cakupan pemberian ASI eksklusif sebesar 25,6\%, sedangkan cakupan ASI eksklusif di Kota Surakarta pada tahun 2013 sebesar $55,78 \%$ (LAKIP SKPD DinKes Kota Surakarta, 2014). Data cakupan ASI eksklusif yang diperoleh di Puskesmas Gilingan pada tahun 2014 yaitu sebesar $58,2 \%$. Hal ini menunjukkan bahwa cakupan ASI eksklusif di Kota Surakarta dan Puskesmas Gilingan sudah mencapai target, karena menurut target renstra SKPD Surakarta pada tahun 2013 untuk bayi yang mendapatkan ASI eksklusif harus mencapai $43 \%$. 
Berdasarkan laporan dari data SKDN pada bayi usia 0-12 bulan yang diperoleh pada tahun 2014 di Puskesmas Gilingan dengan indikator N/D (jumlah anak yang berat badannya naik dibandingkan dengan jumlah anak yang ditimbang dalam \%) didapatkan sebesar $76 \%$, yang menunjukkan bahwa data pertumbuhan bayi di Puskesmas Gilingan masih belum memenuhi target. Target untuk menunjukkan data pertumbuhan bayi berdasarkan indikator N/D yang baik di Puskesmas Gilingan pada tahun 2014 harus mencapai $79 \%$.

Laporan tentang data morbiditas dari Puskesmas Gilingan untuk penyakit ISPA dan diare pada bayi usia 0-12 bulan tahun 2014, diperoleh bayi yang pernah mengalami penyakit ISPA (non pneumonia) sebanyak 58,99\% dan bayi yang pernah mengalami sakit diare sebanyak $5,58 \%$. Hal ini menunjukkan bahwa di Puskesmas Gilingan untuk kejadian ISPA pada bayi masih tergolong tinggi dan masih ada juga bayi yang pernah menderita diare. Berdasarkan uraian tersebut yang mendasari peneliti untuk melakukan penelitian di wilayah Puskesmas Gilingan, dengan judul "Pertumbuhan dan Tingkat Morbiditas pada Bayi Usia 7-12 Bulan Berdasarkan Status Pemberian ASI di Wilayah Puskesmas Gilingan Kecamatan Banjarsari Surakarta”.

\section{METODE PENELITIAN}

Jenis penelitian ini adalah Observasional dengan rancangan studi cohort retrospektif. Penelitian ini dilakukan pada tanggal 2-21 april 2015, dilaksanakan di posyandu wilayah Puskesmas Gilingan Kecamatan Banjarsari Surakarta.

\section{Responden}

Populasi dalam penelitian ini adalah seluruh bayi yang berusia 7-12 bulan yang bertempat tinggal di wilayah Puskesmas Gilingan. Jumlah sampel diperoleh masing-masing kelompok sebanyak 29 responden, dengan menggunakan cara consecutive sampling.

\section{Variabel dan Instrumen Penelitian}

Variabel penelitian ini meliputi variabel bebas yaitu status pemberian ASI dan variabel terikatnya yaitu pertumbuhan bayi, kajadian ISPA dan kejadian diare yang diambil saat bayi masih usia 0-6 bulan. Instrumen yang digunakan pada penelitian ini yaitu form kuesioner karakteristik responden, form inforned consent, form kuesioner tentang status pemberian ASI, form kuesioner tentang tingkat morbiditas dan KMS.

\section{Jenis dan Sumber Data}

Jenis data yang digunakan dalam pengumpulan data yaitu dengan kuantitatif. Sumber data terdiri dari data primer dan data sekunder. Data primer yaitu data yang diperoleh secara langsung dari sampel penelitian. Data tersebut meliputi, karakteristik responden dan subjek penelitian (nama, umur, jenis kelamin, pendidikan, pekerjaan); data tentang status pemberian ASI Eksklusif dari subjek penelitian; data tentang tingkat morbiditas bayi yang meliputi ISPA dan diare dari subjek penelitian. Data sekunder adalah data yang diperoleh dari sumber lain yang sudah ada. Data sekunder dalam penelitian ini adalah grafik pertumbuhan bayi dari KMS, data SKDN dan data kohort bayi dari setiap posyandu di wilayah Puskesmas Gilingan dan gambaran umum Puskesmas Gilingan Banjarsari Surakarta.

\section{Analisis Data}

Analisis data menggunakan analisis bivariat uji Chi Square dengan $\alpha=0,05$ dan tingkat kepercayaan $95 \%$ dan ukuran asosiasi yang digunakan adalah Relative Risk (RR). 


\section{HASIL DAN PEMBAHASAN}

\section{Gambaran Umum Wilayah Kerja Puskesmas Gilingan}

Wilayah kerja Puskesmas Gilingan terdapat 3 kelurahan, yaitu Kelurahan Gilingan, Kelurahan Kestalan, Kelurahan Punggawan. Wilayah Puskesmas Gilingan memiliki 32 posyandu. Posyandu yang terdapat di Kelurahan Gilingan sebanyak 22 posyandu, Kelurahan Kestalan terdapat 4 posyandu dan di Kelurahan Punggawan terdapat 6 posyandu.

\section{Karakteristik Responden}

Data karakterisitk orang tua atau responden penelitian ini untuk mengetahui distribusi dari umur ibu, tingkat pendidikan ibu dan status pekerjaan ibu.

Tabel 1. Distribusi Umur Ibu Bayi

\begin{tabular}{ccc}
\hline Umur Ibu & Frekuensi & Persentase (\%) \\
\hline 20-35 tahun & 48 & 82,8 \\
$>35$ tahun & 10 & 17,2 \\
\hline Total & 58 & 100 \\
\hline
\end{tabular}

Berdasarkan karakteristik umur ibu, ibu sebagai responden sebagian besar berumur antara 20-35 tahun yaitu sebesar 82,8\%. Hasil penelitian Megawati et al., (2012) menunjukkan bahwa umur ibu berhubungan dengan pertumbuhan bayi. Arini (2012) menjelaskan bahwa umur ibu berpengaruh pada kesehatan bayi, karena berkaitan dengan kondisi kehamilan, persalinan dan nifas serta cara mengasuh dan menyusui bayinya.

Tabel 2. Distribusi Pekerjaan Ibu

\begin{tabular}{ccc}
\hline Pekerjaan Ibu & Frekuensi & $\begin{array}{c}\text { Persentase } \\
(\mathbf{\%})\end{array}$ \\
\hline Ibu Rumah Tangga & 38 & 65,5 \\
Swasta & 14 & 24,1 \\
Guru & 1 & 1,7 \\
PNS & 3 & 5,2 \\
Buruh & 2 & 3,4 \\
\hline Total & 58 & 100 \\
\hline
\end{tabular}

Berdasarkan Tabel 2, frekuensi paling banyak terdapat pada ibu yang tidak bekerja atau sebagai ibu rumah tangga yaitu sebesar $65,5 \%$ dan pekerjaan ibu yang paling sedikit yaitu sebagai guru sebanyak $1,7 \%$. Pekerjaan ibu berkaitan dengan waktu yang digunakan untuk berkumpul dengan bayinya. Ibu yang bekerja, biasanya banyak melakukan aktivitas di luar rumah yang mengakibatkan berkurangnya waktu untuk bersama dengan anaknya, sehingga akan mempengaruhi ibu dalam memberikan pola asuh terhadap anaknya.

Tabel 3. Distribusi Pendidikan Ibu

\begin{tabular}{|c|c|c|}
\hline Pendidikan Ibu & Frekuensi & $\begin{array}{c}\text { Persentase } \\
(\%)\end{array}$ \\
\hline SD & 7 & 12,1 \\
\hline SMP & 15 & 25,9 \\
\hline SMA/SMK & 28 & 48,3 \\
\hline Akademi & 1 & 1,7 \\
\hline $\mathrm{S} 1$ & 7 & 12,1 \\
\hline Total & 58 & 100 \\
\hline
\end{tabular}

pendidikan ibu yang paling banyak terdapat pada ibu dengan kategori pendidikan tingkat lanjut (SMA/SMK, S1, akademi) dibandingkan dengan ibu ketegori pendidikan tingkat dasar (SD, SMP). Kelompok ibu yang kategori pendidikan tingkat lanjut, paling banyak terdapat pada ibu dengan sekolah terakhir SMA/SMK yaitu sebesar $48,3 \%$, dan yang paling sedikit yaitu ibu dengan sekolah terakhir akademi sebesar 1,7\%.

\section{Karakteristik Bayi atau Subjek Penelitian}

Subjek penelitian pada penelitian ini adalah bayi usia 7-12 bulan yang bertempat tinggal di wilayah Puskesmas Gilingan. Karakteristik subjek penelitian dapat diketahui sebagai berikut.

Tabel 4. Distribusi Usia Bayi

\begin{tabular}{ccc}
\hline Usia Bayi & Frekuensi & Persentase $(\%)$ \\
\hline 7 bulan & 19 & 32,8 \\
8 bulan & 9 & 15,5 \\
9 bulan & 9 & 15,5 \\
10 bulan & 11 & 19 \\
11 bulan & 8 & 13,8 \\
12 bulan & 2 & 3,4 \\
\hline Total & 58 & 100 \\
\hline
\end{tabular}

Berdasarkan Tabel 4 dapat dilihat bahwa karakteristik bayi berdasarkan usia 
terlihat bahwa bayi yang paling banyak saat penelitian yaitu bayi usia 7 bulan yaitu sebanyak $32,8 \%$.

Tabel 5. Distribusi Jenis Kelamin Bayi

\begin{tabular}{ccc}
\hline Jenis Kelamin & Frekuensi & Persentase (\%) \\
\hline Laki-laki & 34 & 58,6 \\
Perempuan & 24 & 41,4 \\
\hline Total & 58 & 100 \\
\hline
\end{tabular}

Berdasarkan Tabel 5, distribusi jenis kelamin subjek penelitian atau bayi sebagian besar berjenis kelamin laki-laki yaitu sebanyak $58,6 \%$, dibandingkan bayi yang berjenis kelamin perempuan.

Tabel 6. Distribusi Lama Pemberian ASI

\begin{tabular}{ccc}
\hline $\begin{array}{c}\text { Lama Pemberian } \\
\text { ASI }\end{array}$ & Frekuensi & $\begin{array}{c}\text { Persentase } \\
(\mathbf{\%})\end{array}$ \\
\hline 0 bulan & 4 & 6,9 \\
1 bulan & 12 & 20,7 \\
2 bulan & 2 & 3,4 \\
3 bulan & 5 & 8,6 \\
4 bulan & 4 & 6,9 \\
5 bulan & 2 & 3.4 \\
6 bulan & 29 & 50,0 \\
\hline Total & 58 & 100 \\
\hline
\end{tabular}

Berdasarkan Tabel 6 diperoleh lama pemberian ASI yang paling banyak pada bayi usia 6 bulan sebesar $50 \%$ yang dapat dikatakan tergolong pemberian ASI eksklusif, dan lama pemberian ASI yang tergolong tidak ASI eksklusif paling banyak terdapat pada bayi usia 1 bulan sebesar $20,7 \%$.

Tabel 7. Distribusi Status Pemberian ASI

\begin{tabular}{ccc}
\hline $\begin{array}{c}\text { Status Pemberian } \\
\text { ASI }\end{array}$ & Frekuensi & $\begin{array}{c}\text { Persentase } \\
(\mathbf{\%})\end{array}$ \\
\hline ASI Eksklusif & 29 & 50 \\
Tidak ASI Eksklusif & 29 & 50 \\
\hline Total & 58 & 100 \\
\hline Berdasarkan & Tabel 7, distribusi
\end{tabular}

status pemberian ASI diperoleh bayi yang mendapatkan ASI eksklusif yaitu sebanyak 50\%, sedangkan bayi yang tidak mendapatkan ASI eksklusif sebanyak $50 \%$.
Tabel 8. Distribusi Pertumbuhan Bayi

\begin{tabular}{ccc}
\hline $\begin{array}{c}\text { Pertumbuhan } \\
\text { Bayi }\end{array}$ & Frekuensi & $\begin{array}{c}\text { Persentase } \\
(\mathbf{\%})\end{array}$ \\
\hline Normal & 18 & 27,6 \\
Kurang & 42 & 72,4 \\
\hline Total & 58 & 100 \\
\hline
\end{tabular}

Berdasarkan Tabel 8 distribusi pertumbuhan bayi didapatkan, bayi yang mengalami pertumbuhan normal sebanyak $27,6 \%$ dan bayi yang mengalami pertumbuhan kurang sebanyak $72,4 \%$. Variabel pertumbuhan bayi diambil dari data sekunder yang diketahui berdasarkan perbandingan berat badan menurut umur $(\mathrm{BB} / \mathrm{U})$ yang terdapat di KMS dari setiap subjek penelitian. Berdasarkan pedoman Buku KIA (2012), pertumbuhan bayi yang normal pada anak sehat dapat diketahui apabila berat badan naik sesuai garis pertumbuhan atau kenaikan berat badan bayi sesuai dengan KBM (Kenaikan Berat Badan Minimal) pada setiap bulannya.

Tabel 9. Distribusi Kejadian ISPA pada Bayi

\begin{tabular}{|c|c|c|}
\hline Kejadian ISPA & Frekuensi & Persentase (\%) \\
\hline Tidak Pernah & 28 & 48,3 \\
\hline Pernah & 30 & 51,7 \\
\hline Total & 58 & 100 \\
\hline
\end{tabular}
kejadian ISPA pada bayi usia 7-12 bulan, didapatkan bayi yang tidak pernah mengalami gejala ISPA sebanyak 48,3\% dan bayi yang pernah mengalami gejala ISPA banyak $51,7 \%$. Penelitian ini untuk kejadian ISPA dilihat saat bayi berusia 0-6 bulan, ditanyakan pernah atau tidak bayi mengalami gejala ISPA. Penentuan kejadian ISPA diketahui dengan bayi pernah mengalami gejala ISPA atau tidak pernah mengalami salah satu gejala gangguan saluran pernapasan meliputi batuk, pilek dengan atau tanda demam atau panas.

Tabel 10. Distribusi Kejadian Diare pada Bayi

\begin{tabular}{ccc}
\hline Kajadian Diare & Frekuensi & Persentase (\%) \\
\hline Tidak Pernah & 41 & 70,7 \\
Pernah & 17 & 29,3 \\
\hline Total & 58 & 100 \\
\hline
\end{tabular}


Berdasarkan Tabel 10, distribusi kejadian diare diperoleh bayi yang tidak pernah mengalami diare lebih banyak yaitu sebanyak $70,7 \%$ dibandingkan dengan bayi yang pernah mengalami diare sebanyak 29,3\%. Variabel kejadian diare dilihat saat bayi berusia 0-6 bulan, ditanyakan apakah bayi pernah mengalami diare atau tidak.

Tabel 11. Distribusi Pertumbuhan Bayi Berdasarkan Status Pemberian ASI

\begin{tabular}{|c|c|c|c|c|c|}
\hline \multirow[b]{2}{*}{ Status Pemberian ASI } & \multicolumn{2}{|c|}{ Pertumbuhan } & \multirow[b]{2}{*}{ Total } & \multirow[b]{2}{*}{$p$} & \multirow[b]{2}{*}{$\mathbf{R R}$} \\
\hline & $\begin{array}{c}\text { Pertumbuhan } \\
\text { Normal }\end{array}$ & $\begin{array}{c}\text { Pertumbuhan } \\
\text { Kurang }\end{array}$ & & & \\
\hline \multirow[t]{2}{*}{ Eksklusif } & 10 & 19 & 29 & 0,378 & 1,667 \\
\hline & $34,5 \%$ & $65,5 \%$ & $100 \%$ & & $(0,697-$ \\
\hline \multirow[t]{2}{*}{ Tidak Eksklusif } & 6 & 23 & 29 & & $3,984)$ \\
\hline & $20,7 \%$ & $79,3 \%$ & $100 \%$ & & \\
\hline
\end{tabular}

Berdasarkan hasil analisis diperoleh, frekuensi baik ( $\geq 8 \mathrm{kali} /$ hari). Menurut Arif pertumbuhan bayi dari kelompok bayi yang diberikan ASI eksklusif dan kelompok yang tidak mendapatkan ASI eksklusif, bayi yang mengalami pertumbuhan kurang banyak terdapat pada kelompok bayi yang tidak mendapatkan ASI eksklusif sebanyak 79,3\%. Hasil analisis pengaruh pemberian ASI terhadap pertumbuhan bayi didapatkan nilai RR 1,667 (IK 95\% = 0,697 - 3,984), dapat disimpulkan bahwa status pemberian ASI bukan merupakan faktor risiko terhadap pertumbuhan bayi di wilayah Puskesmas Gilingan. Nilai $p=0,378$, yang menunjukkan bahwa pada penelitian ini tidak ada hubungan atau tidak ada pengaruh antara status pemberian ASI terhadap pertumbuhan bayi usia 7-12 bulan di Wilayah Puskesmas Gilingan.

Hasil penelitian juga diperoleh bayi yang mendapatkan ASI eksklusif masih ada yang mengalami pertumbuhan kurang sebesar 65,5\%. Berdasarkan hasil wawancara yang dilakukan pada responden atau ibu dari bayi yang diberikan ASI eksklusif namun memiliki pertumbuhan kurang, sebanyak 68,42\% responden diketahui selama pemberian ASI eksklusif tidak diberikan sesuai dengan frekuensi pemberian ASI yang baik ( $<8 \mathrm{kali} / \mathrm{hari}$ ) dan sebanyak 31,58\% (2009), bayi yang mendapatkan ASI cukup atau dengan frekuensi yang tepat, dapat diketahui dengan bayi akan mengalami penambahan berat badan yang signifikan. Berdasarkan hasil dari penelitian ini dapat diketahui bahwa bayi yang diberikan ASI namun dalam pemberiannya tidak dengan frekuensi yang baik, akan menyebabkan bayi mengalami pertumbuhan kurang. Bayi yang tidak mendapatkan ASI dengan frekuensi yang baik dapat menyebabkan bayi tidak cukup memperoleh ASI sebagai zat gizi yang digunakan sebagai proses pertumbuhan. Pemberian ASI yang baik, lebih baik diberikan sesuai dengan kebutuhan dan keinginan bayi.

Bayi yang mengalami pertumbuhan kurang dapat juga disebabkan dari faktor lain. Terdapat banyak faktor yang dapat mempengaruhi pertumbuhan pada bayi, berdasarkan hasil penelitian ini bayi yang mengalami pertumbuhan kurang juga dapat dipengaruhi oleh adanya penyakit infeksi pada bayi yang mengalami penyakit ISPA atau mengalami diare pada usia tertentu. Hal tersebut ditegaskan oleh Soetjiningsih (2014), bahwa keadaan kesehatan, gizi dan pertumbuhan pada bayi sangat berhubungan erat. 
Tabel 12. Distribusi Kejadian ISPA Berdasarkan Status Pemberian ASI

\begin{tabular}{|c|c|c|c|c|c|}
\hline \multirow[t]{2}{*}{ Status Pemberian ASI } & \multicolumn{2}{|c|}{ Kejadian ISPA } & \multirow[b]{2}{*}{ Total } & \multirow[b]{2}{*}{$p$} & \multirow[b]{2}{*}{$\mathbf{R R}$} \\
\hline & $\begin{array}{l}\text { Tidak Pernah } \\
\text { ISPA }\end{array}$ & Pernah ISPA & & & \\
\hline Eksklusif & 18 & 11 & 29 & & \\
\hline & $62,1 \%$ & $37,9 \%$ & $100 \%$ & 0,066 & 1,800 \\
\hline Tidak Eksklusif & $\begin{array}{c}10 \\
34,5 \%\end{array}$ & $\begin{array}{c}19 \\
65,5 \%\end{array}$ & $\begin{array}{c}29 \\
100 \%\end{array}$ & 0,000 & $1,011-3,204)$ \\
\hline
\end{tabular}

Berdasarkan Tabel 12 diketahui bahwa sebagian besar bayi yang mendapatkan ASI eksklusif tidak pernah mengalami ISPA $(62,1 \%)$, sebaliknya sebagian besar bayi yang tidak mendapatkan ASI eksklusif pernah mengalami ISPA $(65,5 \%)$. Hasil analisis pengaruh pemberian ASI terhadap kejadian ISPA pada bayi didapatkan nilai RR 1,800 (IK 95\% = 1,011 - 3,204), yang berarti bahwa faktor risiko tersebut bermakna. Nilai $p=0,066$, yang menunjukkan bahwa pada penelitian ini tidak terdapat hubungan atau pengaruh antara status pemberian ASI terhadap kejadian ISPA pada bayi usia 7-12 bulan. Hasil dari nilai RR pada penelitian ini dapat diambil kesimpulan bahwa status pemberian ASI memiliki peluang sebagai faktor risiko terhadap kejadian ISPA pada bayi di wilayah Puskesmas Gilingan, walaupun dari hasil nilai $p$ tidak bermakna.

Status pemberian ASI bisa menjadi peluang sebagai faktor risiko kejadian ISPA pada bayi, dapat dijelaskan karena pemberian ASI eksklusif merupakan salah satu upaya untuk mencegah kejadian ISPA pada bayi. ASI dapat memberikan imunisasi pasif melalui kandungan antibodi dan sel-sel imunokompeten ke permukaan saluran pernapasan atas (Hidayat, 2009). Kandungan antibodi dari ASI antara lain sekretori $\operatorname{IgA}(\operatorname{sIg} \mathrm{A})$ memegang peranan pada saluran nafas atas yang berperan dalam mempertahankan integritas mukosa saluran nafas, dan IgG memegang peranan penting pada saluran nafas bagian bawah. Kandungan SIgA yang terdapat dalam ASI, memiliki aktivitas antibodi terhadap virus-virus yang dapat menyebabkan infeksi saluran pernapasan. Kandungan ASI selain sIgA terdapat juga zat kekebalan seluler dalam bentuk sel-sel macrophage (leukosit) yang juga dapat membantu melindungi dan mencegah infeksi lain dari luar. Bayi yang mendapatkan ASI secara eksklusif akan mendapatkan SIgA dan zat kekebalan lainnya dengan cukup, sehingga bayi akan jarang terserang penyakit infeksi saluran pernapasan secara umum (Resch, 2009; Prameswari, 2009).

Hasil penelitian juga didapatkan bayi yang mendapatkan ASI eksklusif masih ada yang pernah mengalami ISPA yaitu sebesar $37,9 \%$. Hal ini dapat disebabkan karena terdapat faktor-faktor lain yang dapat mempengaruhi kejadian ISPA pada bayi. Trisnawati dan Khasanah (2013) menjelaskan bahwa terdapat pengaruh faktor lain yang dapat menyebabkan kejadian ISPA pada bayi, seperti kondisi rumah yang tidak sehat dan adanya anggota kelurga yang merokok di dalam rumah, sehingga kondisi lingkungan sekitar juga sangat mempengaruhi kejadian ISPA pada bayi. 
Tabel 13. Distribusi Kejadian Diare Berdasarkan Status Pemberian ASI

\begin{tabular}{cccccc}
\hline \multirow{2}{*}{ Status Pemberian ASI } & \multicolumn{2}{c}{ Kejadian Diare } & & & \multirow{2}{*}{ Total } \\
\cline { 2 - 4 } & $\begin{array}{c}\text { Tidak Pernah } \\
\text { Diare }\end{array}$ & $\begin{array}{c}\text { Pernah } \\
\text { Diare }\end{array}$ & & & RR \\
\hline Eksklusif & 22 & 7 & 29 & 0,564 & $1,158(0,829-1,618)$ \\
Tidak Eksklusif & $75,9 \%$ & $24,1 \%$ & $100 \%$ & & \\
& 19 & 10 & 29 & & \\
\hline
\end{tabular}

Berdasarkan Tabel 13 diketahui bahwa sebagian besar bayi yang tidak pernah mengalami diare terdapat pada bayi yang diberikan ASI eksklusif $(75,9 \%)$ begitu juga dengan bayi yang tidak mendapatkan ASI eksklusif $(65,5 \%)$. Hasil analisis pengaruh pemberian ASI eksklusif terhadap kejadian diare pada bayi didapatkan nilai RR 1,158 (IK 95\% = 0,829 - 1,618), yang berarti faktor risiko tersebut tidak bermakna, sehingga dapat disimpulkan bahwa status pemberian ASI bukan merupakan faktor risiko terhadap kejadian diare pada bayi di wilayah Puskesmas Gilingan. Nilai $p=0,564$, yang menunjukkan bahwa pada penelitian ini tidak terdapat hubungan atau tidak ada pengaruh antara status pemberian ASI terhadap kejadian diare pada bayi usia 712 bulan.

Tidak adanya pengaruh antara status pemberian ASI terhadap kejadian diare pada penelitian ini sejalan dengan penelitian yang dilakukan oleh Risnanda (2013), yang menjelaskan bahwa tidak ada hubungan antara status pemberian ASI dengan kejadian diare pada bayi. Hal ini bisa disebabkan karena kejadian diare pada bayi dapat dipengaruhi dari beberapa faktor. Menurut teori Purwanti (2004), menjelaskan bahwa penyebab diare pada bayi dapat disebabkan dari beberapa faktor, salah satunya faktor dari bayi atau individu adalah adanya infeksi baik di dalam atau pun di luar saluran pencernaan baik itu infeksi bakteri, virus, maupun infeksi parasit.

Berdasarkan penelitian ini, pemberian MPASI yang belum waktunya atau pemberian MPASI sebelum bayi usia
6 bulan juga dapat menjadi salah satu penyebab terjadinya penyakit diare pada bayi. Berdasarkan hasil penelitian Nutrisiani (2010) menjelaskan anak yang diberikan makanan pendamping ASI pada usia tidak tepat (sebelum usia 6 bulan) mempunyai risiko 1,256 kali lebih besar untuk terpapar diare dibandingkan dengan anak yang diberi makanan pendamping ASI pada usia yang tepat (usia lebih dari 6 bulan). DepKes RI (2006), menjelaskan bahwa makanan pendamping ASI yang tepat lebih baik diberikan ketika anak sudah berusia lebih dari 6 bulan, agar anak tidak mengalami infeksi atau gangguan pencernaan akibat virus atau bakteri. Sistem pencernaan bayi juga masih sangat lemah dan rentan, sehingga bayi dapat sering mengalami diare, alergi dan penyakit infeksi.

\section{KESIMPULAN}

1. Nilai RR 1,667 (IK 95\% =0,6973,984 ) yang berarti status pemberian ASI bukan faktor risiko terhadap pertumbuhan bayi. Nilai $p=0,378$ dengan kesimpulan, tidak ada pengaruh antara status pemberian ASI terhadap pertumbuhan bayi usia 7-12 bulan di Wilayah Puskesmas Gilingan Banjarsari Surakarta.

2. Nilai RR 1,800 (IK 95\% = 1,011 $3,204)$, yang berarti status pemberian ASI memiliki peluang sebagai faktor risiko terhadap kejadian ISPA pada bayi. Nilai $p=0,066$ dengan kesimpulan, bahwa tidak terdapat pengaruh antara status pemberian ASI terhadap kejadian ISPA pada bayi 
usia 7-12 bulan di Wilayah Puskesmas Gilingan Banjarsari Surakarta.

3. Nilai RR 1,158 (IK $95 \%=0,829-$ 1,618), yang berarti status pemberian ASI bukan faktor risiko terhadap kejadian diare pada bayi. Nilai $p=$
0,564 dengan kesimpulan bahwa, tidak ada pengaruh antara status pemberian ASI terhadap kejadian diare pada bayi usia 7-12 bulan di Wilayah Puskesmas Gilingan Banjarsari Surakarta.

\section{DAFTAR PUSTAKA}

Arif, N., 2009, Panduan Ibu Cerdas-ASI dan Tumbuh Kembang Bayi, Media Pressindo, Yogyakarta.

Arini., 2012, Seorang Ibu Harus Menyusui, Flash Books, Yogyakarta.

Buku Profil Kesehatan Provinsi Jawa Tengah Tahun 2012, Dinas Kesehatan Provinsi Jawa Tengah.

Departemen Kesehatan RI 2006, Pedoman Umum Pemberian Makanan Pendamping Air Susu Ibu (MP ASI Lokal), http://www.depkes.org.id, Diakses tanggal 22 Maret 2012.

Departemen Kesehatan RI, 2009, Pedoman Pengendalian Penyakit Infeksi Saluran Pernapasan Akut. Departemen Kesehatan Republik Indonesia. Jakarta.

Fitriyah, H dan Sulistyawati, T., 2013, Hubungan Status Pemberian ASI Eksklusif Dengan Kejadian Morbiditas Pada Bayi Umur 7-12 Bulan Di Kota Semarang. Vol. 3 no.1 Januari 2013.

Megawati, R. A., Harsoyo N., Afiana R., 2012, Hubungan Pola Pemberian ASI dan Karakteristik Ibu dengan Tumbuh Kembang Bayi 0-6 Bulan di Desa Bajomulyo, Juwana, Jurnal Kedokteran Universitas Muhammadiyah Semarang, Volume 1, Nomor 1, Tahun 2012.

Hidayat, 2009, Faktor-Faktor yang Berhubungan dengan Kejadian Penyakit ISPA pada Balita di Kelurahan Pasie Nan Tigo Kecamatan Koto Tangah Kota Padang, http://www.springerlink.com, Diakses tanggal 11 Oktober 2009.

Kementerian Kesehatan RI., 2012, Buku Kesehatan Ibu dan Anak, Kementerian Kesehatan dan JICA, Jakarta.

Laporan Akuntabilitas Kinerja Instansi Pemerintah (LAKIP) SKPD Dinas Kesehatan Kota Surakarta, 2014, Dinas Kesehatan Kota Surakarta Tahun 2014, Surakarta.

Nutrisiani, F., 2010, Hubungan Pemberian Makanan Pendamping Air Susu Ibu (MP ASI) pada Anak Usia 0-24 Bulan dengan Kejadian Diare Di Wilayah Kerja Puskesmas Purwodadi Kecamatan Purwodadi Kabupaten Grobogan Tahun 
2010, Skripsi, Program Studi Kesehatan Masyarakat Fakultas Ilmu Kesehatan Universitas Muhammadiyah Surakarta.

Prameswari, GN., 2009, Hubungan Lama Pemberian ASI Secara Eksklusif Dengan Frekuensi Dengan Frekuensi Kejadian ISPA, Jurusan Ilmu Kesehatan Masyarakat, Fakultas Ilmu Keolahragaan, Universitas Negeri Semarang, Indonesia, Jurnal KEMAS 5 (1) (2009) 27-33, ISSN 1858-1196.

Purwanti, SH., 2004, Konsep Penerapan ASI Eksklusif, EGC, Jakarta.

Resch, 2009, The Impact of Respiratory Syncytial Virus Infection: A Prospective Study in Hospitalized Infants Younger than 2 Years, http://www.springerlink.com, Diakses tanggal 15 Oktober 2009.

Riset Kesehatan Dasar, 2013, Badan Penelitian dan Pengembangan Kesehatan, Kementerian Kesehatan RI 2013, Jakarta.

Risnanda, L., 2013, Hubungan Pemberian ASI dengan Kejadian Diare pada Bayi Usia 0-6 Bulan di Wilayah Kerja Puskesmas Blang Bintang Kecamatan Blang Bintang Kabupaten Aceh Besar, Jurnal stikes U'Budiyah banda Aceh D-IV Kebidanan.

Sinaga, EK., 2012, Kualitas Lingkungan Fisik Rumah dengan Kejadian Infeksi Saluran Pernapasan Akut (ISPA) pada Balita di Wilayah Kerja Puskesmas Kelurahan Warakas Kecamatan Tanjung Priuk Jakarta Utara Tahun 2012, Skripsi, Universitas Indonesia.

Siregar, A., 2004, Pemberian ASI Eksklusif dan Faktor-Faktor yang Mempengaruhinya, Jurnal Gizi Kesehatan Masyarakat 2004; 3(2): 81-92.

Soetjiningsih., 2014, Tumbuh Kembang Anak, EGC, Jakarta

Sulistyoningsih, H., 2010, Gizi Untuk Kesehatan Ibu dan Anak, Graha Ilmu, Yogyakarta.

Suraatmaja, S., 2007, Kapita Salekta Gastroenterologi Anak, CV Agung Seto, Jakarta.

Trisnawati, Y dan Khasanah, K., 2013, Analisis Faktor Intrinsik dan Ekstrinsik yang Berpengaruh Terhadap Infeksi Saluran Pernapasan Akut (ISPA) pada Balita Tahun 2013, Jurnal Kebidanan, Vol. V, No. 01, Juni 2013. 
JURNAL KESEHATAN, ISSN 1979-7621, Vol. 10, No. 1. Juni 2017 